\title{
Are plant pathogen populations adapted for encounter with their host? A case study of phenological synchrony between oak and an obligate fungal parasite along an altitudinal gradient
}

\author{
M.-L. DESPREZ-LOUSTAU*, Y. VITASSE $\uparrow, S$. DELZON†, X. CAPDEVIELLE*, B. MARÇAIS \& \& \\ A. KREMER§ \\ *INRA, UMR1202 BIOGECO, Pathologie forestière, rue Edouard Bourlaux, Villenave d'Ornon, France \\ †Université Bordeaux 1, UMR1202 BIOGECO, Ecologie des communautés, Bâtiment B8, Talence, France \\ \$INRA, UMR1136 Interactions Arbres-Microorganismes, Champenoux, France \\ §INRA, UMR1202 BIOGECO, Génétique, Domaine de l'Hermitage, Pierroton, Cestas, France
}

\author{
Keywords: \\ climate warming; \\ disease avoidance; \\ Erysiphe alphitoides; \\ local adaptation; \\ phenology; \\ plant pathogen; \\ Quercus; \\ synchrony.
}

\begin{abstract}
Biotrophic fungal pathogens are expected to have adapted to their host plants for phenological synchrony, to optimize the possibility of contacts leading to infections. We investigated the patterns and causes of variation in phenological synchrony in the oak-powdery mildew pathosystem, a major disease in natural ecosystems. The study was carried out along an altitudinal gradient, representing a wide temperature range, in mature oak stands. Both sporulation (pathogen infective stage) and oak flushing (host susceptible stage) were delayed with increasing elevation, but with a significantly different sensitivity for the two species. This resulted in a variable host-pathogen synchrony along the gradient. A common garden experiment did not give evidence of amongpopulation genetic differentiation (past adaptation) for fungal phenology. This could be explained by the high phenotypic variation in phenology within host populations, precluding selection on fungal phenology at the population scale, but possibly favouring adaptation at the within-population scale. Phenotypic plasticity was the major cause of the observed variation in the phenology of the fungal populations.
\end{abstract}

\section{Introduction}

Plants are constantly challenged by other organisms. Their ability to convert inorganic molecules into a carbohydrate source of energy makes them an attractive target to parasitic species, especially fungi. In their longlasting and complex dialogue, plants and parasites have evolved mechanisms which determine the outcome of their interaction. To explain parasite success on a potential host, Combes (2001) proposed a conceptual framework based on two 'filters': the encounter filter and the compatibility filter. The encounter filter determines whether and to what extent the parasite can find the host. This may include overlap between geographical

Correspondence: Marie-Laure Desprez-Loustau, INRA, UMR1202 BIOGECO, Pathologie forestière, Domaine de l'Hermitage, Cestas, France. Tel.: +33(5)57122843; fax: +33(5)57122881;

e-mail:mloustau@pierroton.inra.fr distributions of host and parasite (at different spatial scales), temporal match or behaviours. The compatibility filter determines infection and reproduction success of the parasite once it makes contact with the host. This includes molecules produced by either parasite or host linked to pathogenicity/virulence or defense/resistance. Selective pressure is on both parasites and hosts to open or close the filters, affecting their behaviour to chase or avoid each other and their constitutive and inducible molecules to attack or resist each other. The opening of filters is not only determined by host and parasite genotypes but also by environmental factors. The two filters also do no act independently: high encounter rates can produce selection for host resistance (Ovaskainen $\delta$ Laine, 2006). The degree of opening of both filters eventually determines the occurrence and extent of parasitic exploitation. In this view, the encounter and compatibility filters explain the range of species that 
parasites are able to exploit but also differences in parasite performance in different host populations or subpopulations.

Research on plant-fungal pathogen interactions and their evolutionary dynamics has mainly focused on the so-called compatibility filter, i.e. pathogenicity/virulence and defense/resistance traits. The understanding of the molecular dialogue between plants and their pathogens has greatly improved in recent years (see Jones $\&$ Dangl, 2006; Bent \& Mackey, 2007; Egan \& Talbot, 2008 for reviews). A substantial body of information, at gene and population levels, supports the existence of reciprocal selection processes where plant resistance and pathogen virulence undergo continual adaptation in response to each other (de Meaux \& Mitchell-Olds, 2003; Meyers et al., 2005; Tiffin \& Moeller, 2006; Salvaudon et al., 2008). In particular, local adaptation of parasites to their host plants has been investigated in different systems and shown to occur in most of them, as expected from theoretical considerations (Gandon \& Michalakis, 2002; Greischar \& Koskella, 2007). In these studies, the fitness traits characterizing adaptation were mostly host exploitation ability and resistance/defense, i.e. traits related to host-pathogen physiological compatibility, both in theoretical (Kaltz \& Shykoff, 1998) and in experimental approaches, especially by using cross-inoculations (Greischar \& Koskella, 2007; Sicard et al., 2007).

Comparatively little has been described related to the encounter filter in plant-pathogen interactions. Burdon (1987) defined disease avoidance as a set of mechanisms under the genetic control of the host which minimize contact with the pathogen. These mechanisms have been neglected in plant breeding but may play an important role in natural populations where they would be selectively favoured by pathogen pressure (Burdon, 1987). Such mechanisms have been well studied in the model pathosystem Silene latifolia-Microbotryum violaceum, the anthersmut disease, where flower phenology and morphology were shown to be important traits explaining variation in disease through the probability of pathogen contact (e.g. in Alexander et al., 1993; Elmqvist et al., 1993; Thrall \& Jarosz, 1994; Biere \& Antonovics, 1996; Biere \& Honders, 1996; Shykoff et al., 1997). In particular, sexual dimorphism related to flowering behaviour could explain sexbiaised infection rates in Silene latifolia (Thrall \& Jarosz, 1994; Biere \& Antonovics, 1996; Biere \& Honders, 1996; Kaltz \& Shykoff, 2001). Variation in infection linked to synchrony between host-plant phenology and pathogen activity has been reported for some other diseases, such as pine twisting rust (Desprez-Loustau \& Dupuis, 1994), mummy berry disease of blueberry (Penman \& Annis, 2005) or sudden oak death (Dodd et al., 2008). From the fungus side, the encounter filter may not be critical for many species that are able to sustain saprotrophic growth in the absence of the host and/or to infect a broad host range. Conversely, the encounter filter is expected to be crucial for obligate biotroph pathogens, especially with narrow host range, such as rust and powdery mildew agents. For these pathogens, the encounter filter can include a temporal component when susceptible stages of the host occur only during a limited period of time. This is typically the case when susceptible organs are young leaves or shoots in temperate regions with a strong seasonality of growth. Plant pathogens are then expected to synchronize their phenology with that of their host to maximize their fitness. Little attention has been paid to the selection pressure exerted by plant phenology on pathogenic fungi (but see Lehman \& Oudemans, 1997). Conversely, this has been investigated in several tree-insect interactions, where local phenological adaptation of insect herbivores to their host trees has been demonstrated (Van Ash \& Visser, 2007).

A better understanding of the ecological and evolutionary forces underlying host-pathogen phenological synchrony is of particular interest in the context of ongoing climate change, especially climate warming. Temperature has been shown to be a major driving factor for plant phenology (Cannell \& Smith, 1983; Hanninen, 1995; Chuine \& Cour, 1999) and is also likely to be important for fungal phenology (Desprez-Loustau et al., 1998; Scherm et al., 2001; Rossi et al., 2008). However, responses are likely to differ among species, which will affect phenological match between associated species (Memmott et al., 2007). Indeed, synchrony does not necessarily imply that the same mechanisms related to the use of environmental cues are used by plants and their associated organisms (Van Ash \& Visser, 2007). For example, the recent change in temperature patterns has been considered as the main reason for the increased mis-timing in the winter moth-oak system (Visser \& Holleman, 2001). More generally, disentangling plastic from evolutionary responses of populations for coping with environmental changes is an important current scientific issue (Gienapp et al., 2008).

Altitudinal gradients, with sharp variations in environmental factors (especially temperature) provide a good opportunity to study the effect of differential long-term selection regimes in promoting population differentiation for adaptive traits, such as phenology. In the case of plant-pathogen systems, pathogen populations will evolve on highly spatially heterogeneous hosts for phenology along the gradient. Do patterns of local phenological adaptation of pathogen populations, such as those hypothesized and observed for the compatibility filter, occur for the encounter filter? If so, which among the different adaptive processes hypothesized by Gandon \& Van Zandt (1998) can be observed: plastic behaviour, generalist or specialist strategy of parasite adaptation to the host phenology?

We explore these questions in this study, focusing on oak powdery mildew, caused by the Ascomycete fungus Erysiphe alphitoides. This major disease of oaks in Europe (Butin, 1995) presents characteristics in the strategy and life cycle of the pathogen and in the host-pathogen 
interaction suggesting the importance of the encounter filter, which is also supported by field observations (M.-L. Desprez-Loustau \& A. Dugravot, unpublished results). Our objective was to investigate the patterns and causes of variation in host-parasite phenological synchrony along a transect in the Pyrenees mountains. The following specific questions were addressed:

(1) What is the extent of phenotypic variation in spring phenology (timing of infective stage) between powdery mildew populations, and does it match that of oak (timing of susceptible stage) along the altitudinal gradient (phenological synchrony)?

(2) Can the observed patterns of phenotypic variation between populations of the pathogen be explained by genetic differentiation or/and by environmental factors?

(3) Does the level of host-pathogen synchrony, determining the encounter rate, actually result in higher infection, therefore potentially affect host and pathogen fitness?

\section{Materials and methods}

\section{Study system}

Erysiphe alphitoides in an obligate biotroph parasite on oaks, mainly Quercus robur and Q. petraea in Europe. The fungus develops its mycelium on the surface of leaves and differentiates infection structures in the epidermal cells of the susceptible hosts. Haustoria serve as absorptive organs from which the fungus derives host metabolites for its own nutrition. Infection results in the production of huge numbers of conidiospores at the leaf surface, leading to the white covering typical of powdery mildews. All stages of the host, from seedlings to mature trees can be infected. However, oaks exhibit ontogenic resistance toward powdery mildew resulting in a narrow susceptibility window of leaves: only young expanding leaves are receptive to the disease (Edwards \& Ayres, 1982). The fungus is also affected by seasonality. During winter, in the absence of available host tissues, powdery mildews can perennate either as mycelium in buds infected in the previous season, or by forming chasmothecia, the sexual fruiting bodies produced in late summer on infected leaves. Primary inoculum in spring, initiating the new epidemics, is then either constituted by flag shoots, i.e. shoots arising from infected buds producing high numbers of conidiospores, or by ascospores, released by chasmothecia (Glawe, 2008). Flagshoots are very rarely observed in oaks, at least in the study area (personal observation). In addition, recent studies provided the first direct evidence of the role of ascospores in initiating the life cycle of E. alphitoides in spring (Marçais et al., 2009). We therefore assumed that ascospores were the main primary inoculum.

Erysiphe alphitoides was described in 1911, as the causal agent of the new epidemics affecting oaks in Europe, but the origin of the species is still unclear (Mougou et al., 2008). Recent studies using internal transcribed spacer polymorphism of the ribosomal DNA demonstrated the occurrence of several cryptic species, beside E. alphitoides, causing oak powdery mildew symptoms (Mougou et al., 2008). In this study, more than $95 \%$ of colonies obtained from chasmothecia from all sites and years were identified as E. alphitoides (unpublished results). Genetic markers for within-species population studies are currently under development but are not yet available (unpublished results).

\section{Study area and sites}

The study was conducted along an altitudinal gradient from 130 to $1630 \mathrm{~m}$ above seal level (asl) in the Pyrenees mountains (southern France, latitude from $42^{\circ} 47^{\prime} \mathrm{N}$ to $43^{\circ} 45^{\prime} \mathrm{N}$; longitude from $00^{\circ} 25^{\prime} \mathrm{W}$ to $00^{\circ} 01^{\prime} \mathrm{E}$ ). This region is characterized by a temperate oceanic climate, with a mean annual temperature of $12{ }^{\circ} \mathrm{C}$ and mean annual precipitation of $1079 \mathrm{~mm}(1946-2001)$ at low elevation (Tarbes, $43^{\circ} 11^{\prime} \mathrm{N}, 00^{\circ} 00^{\prime} \mathrm{W}, 360 \mathrm{~m}$ asl, Météo France). We selected five natural mature stands dominated by sessile oak at different elevations: 131, 427, 803, 1235 and $1630 \mathrm{~m}$, on a South-facing slope (Table 1). Stands were located several kilometres apart from each other with no continuous oak forest cover between

Table 1 Main features of oak population sites in the Pyrénées and of common garden (Villenave d'Ornon).

\begin{tabular}{|c|c|c|c|c|c|c|c|}
\hline \multirow[b]{2}{*}{ Site } & \multirow{2}{*}{$\begin{array}{l}\text { Altitude } \\
\text { (m) }\end{array}$} & \multirow[b]{2}{*}{ Latitude } & \multirow[b]{2}{*}{ Longitude } & \multirow[b]{2}{*}{ Aspect } & \multirow{2}{*}{$\begin{array}{l}\text { dbh } \\
(m)\end{array}$} & \multicolumn{2}{|c|}{$T_{\mathrm{a}}\left({ }^{\circ} \mathrm{C}\right)$} \\
\hline & & & & & & 2006 & 2007 \\
\hline \multicolumn{8}{|l|}{ In situ } \\
\hline Laveyron & 131 & $43^{\circ} 45^{\prime} \mathrm{N}$ & $00^{\circ} 13^{\prime} \mathrm{W}$ & Flat & 1.65 & 13.5 & 12.6 \\
\hline Adé & 427 & $43^{\circ} 08^{\prime} \mathrm{N}$ & $00^{\circ} 00^{\prime} \mathrm{W}$ & South & 1.41 & 13.1 & 12.0 \\
\hline Chèze & 803 & $42^{\circ} 55^{\prime} \mathrm{N}$ & $00^{\circ} 02^{\prime} \mathrm{W}$ & South & 0.63 & 11.9 & 10.7 \\
\hline Gèdre & 1235 & $42^{\circ} 47^{\prime} \mathrm{N}$ & $00^{\circ} 01^{\prime} \mathrm{E}$ & South & 1.37 & 10.7 & 9.5 \\
\hline Péguère & 1630 & $42^{\circ} 52^{\prime} \mathrm{N}$ & $00^{\circ} 07^{\prime} \mathrm{W}$ & South & 0.67 & 8.6 & 7.4 \\
\hline \multicolumn{8}{|l|}{ Common garden } \\
\hline Villenave d'Ornon & 22 & $44^{\circ} 46^{\prime} \mathrm{N}$ & $00^{\circ} 33^{\prime} \mathrm{W}$ & Flat & - & 14.1 & 13.5 \\
\hline
\end{tabular}

$T_{\mathrm{a}}$ corresponds to the mean annual temperature, dbh to the mean diameter at breast height of the population. 
them; they were therefore assumed to represent distinct populations with no massive gene flow between them. The altitudinal gradient provided a temperature range around $5{ }^{\circ} \mathrm{C}$.

\section{Fungus phenology monitoring}

Phenological observations were focused on ascospore release in spring, using oak seedlings as specific spore traps. Trap seedlings were produced in the greenhouse, where sulphur burners were used to prevent powdery mildew contaminations. As oak susceptibility to powdery mildew is highly dependent on ontogenic stage (Edwards \& Ayres, 1982), acorns of Q. robur were sown every 10 days during the whole season and trap seedlings were carefully selected among the greenhouse grown material according to their phenological stage. Only seedlings highly receptive to powdery mildew, i.e. with young and nonfully developed leaves, were used as traps. Seedlings were sprayed with water until dripping to remove sulphur before use. A set of 13 trap-seedlings (representing a target surface area of approximately $200 \mathrm{~cm}^{2}$ ) was brought to each of the five stands along the altitudinal gradient every 10 days from early April to the end of June, in 2006 and 2007, to allow them to be exposed to natural inoculum. The thirteen seedlings were put in a tray and hung in a tree within the stand. For practical reasons, only one lot per altitude could be used at each date. We assumed that this single spore trap gave an estimate of the local inoculum in the oak stand since Roslin et al. (2007) demonstrated highly efficient dispersal of E. alphitoides over several hundred metres. After the 10 days exposure, the lot was taken back to the laboratory and replaced by another healthy trap lot. Seedlings which had been exposed to natural inoculum and taken back from the field were incubated in a growth chamber $\left(18 / 22{ }^{\circ} \mathrm{C}, 8 / 16 \mathrm{~h}\right.$ night-day photoperiod) during 10 days to reveal spore-derived infections. At the end of the incubation period, the overall number of powdery mildew colonies, visible as white spots, was scored on the 13 seedlings. This number was related to the medium date of the exposure period to express the time course of phenology.

To discriminate environmental from genetic determinants of phenology in oak powdery mildew populations along the altitudinal gradient, chasmothecia phenology was also studied under 'common garden' conditions. In late September 2005 and 2006, each powdery mildew population corresponding to each of the five oak stands was sampled by collecting strongly infected leaves from four to five oak trees scattered in the stand. These infected leaves were examined for the presence of chasmothecia under a binocular microscope in the laboratory. Leaves exhibiting a large number of chasmothecia were put in nylon mesh bags with an opening size of $50 \mu \mathrm{m}$, allowing water to pass freely but preventing chasmothecia to be lost. One bag with approximately 250 leaves was prepared for each collection site. All bags were placed on $0.80 \mathrm{~m}$ high horizontal wire mesh frames installed outdoors at the research station, Villenave d'Ornon, for overwintering (Table 1). Chasmothecia phenology was monitored in spring 2006 and 2007 by using trap oak seedlings as explained before. To prevent contaminations from local oak mildew inoculum (and other sources placed at the same site) while allowing chasmothecia to be exposed to ambient temperature and rain, wire-mesh frames were isolated in cages made of nonwoven fabric (Fiberweb agryl P30) in late March of each year. Each cage contained one bag of chasmothecia bearing leaves from one site. From the beginning of April to the end of June, trap seedlings were exposed to the chasmothecia in the cages for periods of 10 days, with 12 seedlings per exposure period and cage, incubated and scored as previously described. Control seedlings put in cages without chasmothecia and incubated as others were very little infected. This provided strong although indirect evidence that most infections observed in seedlings exposed to chasmothecia were ascospore derived and not the result of contaminations.

\section{Oak phenology monitoring}

In each population, spring budburst was monitored on 20-34 mature individuals of comparable height assumed to be a representative sample of the population variation for phenology. Each site was visited every 10 days from 15 March to 31 May to record flushing dates events on all selected individuals in 2006 and 2007. Observations were made using binoculars (magnifying power: 10×), always by the same observer, approximately at $15 \mathrm{~m}$ distance from the tree. The development stage was recorded from bud dormancy to leaf unfolding, using a 5-stage scale (see a full description of the method in Vitasse et al., 2009a), and the percentage of buds that were at the unfolding stage (i.e. with at least one of their leaves fully unfolded) was visually evaluated. The flushing date of a tree was determined when $50 \%$ of the buds had reached the unfolding stage. This date was estimated, for each selected tree, by linear regression between two measurement campaigns.

\section{Oak infection}

In each site, oak infection was assessed in late June 2007. Eight to 12 trees per site were chosen to represent a wide range of phenological variation. Infection for each tree was assessed as follows. Four branches in each of the four cardinal directions were cut from the crown at 4-8 m high, using a pole pruner. Only first flush shoots were present in all trees. From each branch, two current-year shoots were taken and the leaves in second and fifth position on each shoot were scored for the percentage of leaf area infected by oak powdery mildew. The infection 
of each tree was considered as the mean of infection on the 16 leaves.

\section{Data analysis}

Oak-fungus synchrony was studied at the population level in both years. To estimate the receptive period of oaks to powdery mildew in each of the five populations, we considered that the beginning of the receptive period was given by the mean flushing date of the $25 \%$ earliest trees, i.e. in the first quartile. The end was calculated by adding 15 days to the flushing date of the $25 \%$ latest trees, i.e. in the last quartile. A value of 15 days was taken to account for the time when leaves remain receptive to powdery mildew after unfolding (Edwards \& Ayres 1982; M.-L. Desprez-Loustau $\&$ X. Capdevielle, personal observations); we assumed that the development of leaves had similar rates among altitudes because it took place at rather similar temperatures occurring at delayed dates with elevation (Vitasse et al., 2009a). Anyhow, the end of the receptive period of the first flush is of limited importance for synchrony with powdery mildew as several flushes occur during the season.

The beginning of the period of spore (presumably ascospore) production was determined as the day of year when the first 10 spores were estimated to be trapped, based on log interpolation using observations of colonies on the trap seedlings, for each stand and year (see below, Fig. 1). As contaminations of trap seedlings by various
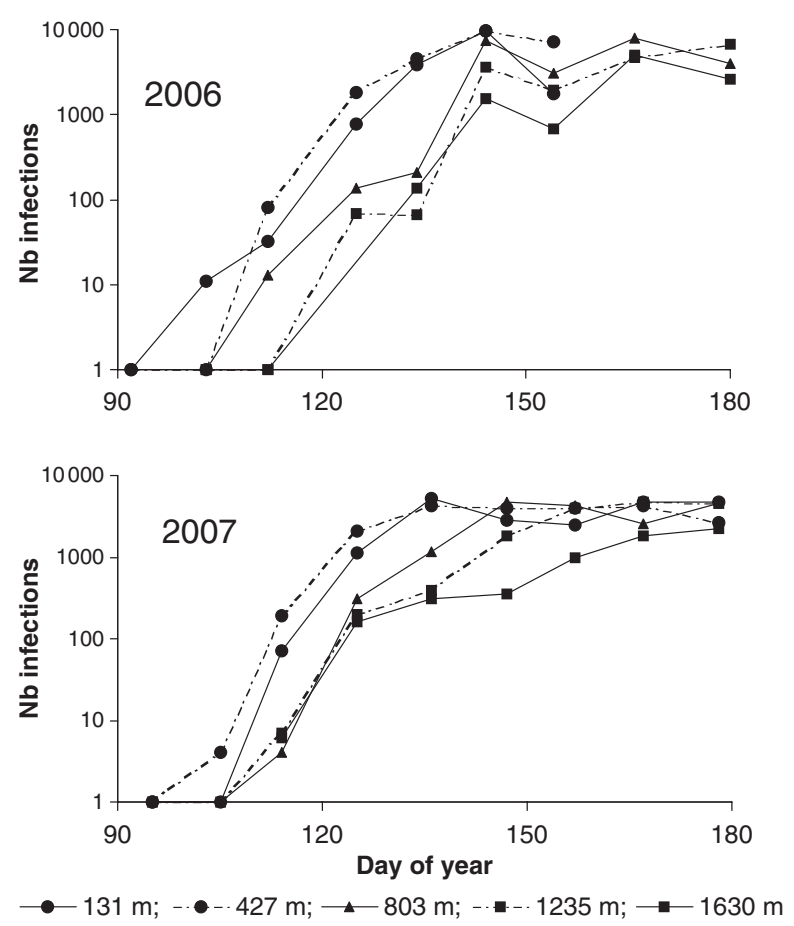

Fig. 1 Spring phenology of oak powdery mildew along the altitudinal gradient, monitored as primary infections on trap seedlings. sources of inoculum cannot be totally ruled out, we tested other indicators presumably less affected by contaminations (e.g. 50 or 100 spores, based on later trapping). All indicators (calculated by linear or loglinear regressions, in absolute or relative values of spore counts) were highly correlated and resulted in parallel curves for their relationship with altitude. Therefore, the estimated threshold of 10 spores was retained.

Statistical analyses were performed with sas 9.1 software (SAS Institute, Cary, NC, USA). The homogeneity of slopes in regressions between phenology and altitude for oak and fungus species was tested by performing a covariance analysis with altitude as the covariate and species the categorical variable (GLM procedure).

\section{Results}

\section{Altitudinal trends in powdery mildew and oak phenology, and host-pathogen synchrony}

A similar altitudinal trend in powdery mildew phenology was observed in both years, with spore detection (as derived infections) starting and peaking earlier at lower altitudes (Fig. 1). Spores were first detected in mid-April at low altitudes but not until early May at the highest altitude. The amplitude of phenological variation across the gradient was approximately 20 days at all dates during the increasing phase of infection progress curve in 2006. The amplitude was slightly smaller at early stages and greater at later stages in 2007. Little difference in the temporal dynamics of infection was observed between the 2 years at each site.

An altitudinal trend was also clearly observed on oak flushing dates: populations at high elevations flushed at later dates than low elevation populations, in both years (Table 2). Oak populations showed large amplitude in flushing date between the lowest and highest populations: approximately 40 days on average between the lowest and highest populations and 60 days between the earliest and the latest individuals in both years (Table 2). The greatest within-population variation was observed at the lowest elevations, with a maximum amplitude of about 1 month for population located at $400 \mathrm{~m}$ (Table 2). Flushing occurred a few days later in 2007 than in 2006 at all elevations.

Although both powdery mildew and oak responded with a delayed phenology to increasing altitude, their responses significantly differed in their amplitude, as shown by the highly significant interaction between species and altitude in the covariance analysis (Table 3 ). While the onset of leaf flushing was delayed by 3.1 days for every $100 \mathrm{~m}$ increase in elevation, the slope was much lower ( 0.9 days per $100 \mathrm{~m}$ on average) for the beginning of sporulation in the 2 years. This resulted in differences in host-parasite synchrony along the gradient (Fig. 2). At low altitudes, earliest trees flushed at a time when no or few spores could be detected with the trap 
Table 2 Flushing dates (in day of year) of oak trees recorded in each site in 2006 and 2007.

\begin{tabular}{|c|c|c|c|c|c|c|c|c|c|c|}
\hline \multirow[b]{2}{*}{ Site } & \multirow[b]{2}{*}{ Altitude } & \multicolumn{4}{|l|}{2006} & \multicolumn{4}{|l|}{2007} & \multirow[b]{2}{*}{$n$} \\
\hline & & $\mathrm{FD}_{\min }$ & $F D_{\max }$ & $\mathrm{FD}_{\text {mean }}$ & $\mathrm{CV}$ & $F D_{\min }$ & $F D_{\max }$ & $\mathrm{FD}_{\text {mean }}$ & $\mathrm{CV}$ & \\
\hline Laveyron & 131 & 91.3 & 111.3 & 98.7 & 7.0 & 87.4 & 115.5 & 100.6 & 8.2 & 20 \\
\hline Adé & 427 & 89.8 & 120.3 & 103.5 & 10.8 & 95.0 & 119.2 & 118.1 & 7.8 & 34 \\
\hline Chèze & 803 & 105.3 & 125.0 & 114.9 & 4.9 & 116.4 & 131.0 & 121.7 & 3.4 & 23 \\
\hline Gèdre & 1235 & 120.6 & 133.4 & 124.4 & 2.9 & 119.2 & 139.0 & 128.5 & 3.2 & 27 \\
\hline Péguère & 1630 & 130.5 & 146.1 & 139.3 & 4.1 & 136.4 & 148.1 & 142.6 & 3.4 & 24 \\
\hline
\end{tabular}

$\mathrm{FD}_{\min }$, the earliest flushing date recorded; $\mathrm{FD}_{\max }$, the latest flushing date recorded; $\mathrm{FD}_{\text {mean }}$, the mean of the flushing dates for the whole population; $\mathrm{CV}$, coefficient of variation $(\%) ; n$, number of individuals monitored in the population.

Table 3 Analysis of covariance with spring phenology (expressed in DOY) as the dependent variable and altitude (covariate), year, species (oak vs. fungus) and interactions as explaining variables.

\begin{tabular}{lrrrc}
\hline $\begin{array}{l}\text { Source of } \\
\text { variation }\end{array}$ & d.f. & $\begin{array}{l}\text { Sum of } \\
\text { squares }\end{array}$ & \multicolumn{1}{c}{$F$} & \multicolumn{1}{c}{$P$} \\
\hline Altitude & 1 & 2299.7 & 179.3 & $<0.0001$ \\
Year & 1 & 25.5 & 2.0 & 0.18 \\
Species & 1 & 548.5 & 42.8 & $<0.0001$ \\
$\quad$ (oak vs. fungus) & & & & \\
Species $\times$ year & 1 & 19.1 & 1.5 & 0.24 \\
Species $\times$ altitude & 1 & 757.7 & 43.9 & $<0.0001$ \\
Error & 14 & 179.6 & & \\
\hline
\end{tabular}

For oaks, the phenological variable was the mean date of leaf unfolding for the $25 \%$ earliest trees. For the powdery mildew fungus, the phenological variable was the date when the first 10 spores were trapped.

seedlings. Conversely, at high altitudes, spores were trapped several days before the earliest trees flushed. Finally, the best phenological match was observed at intermediate altitudes where spores started to be disseminated at the time when oaks started to flush.

\section{Phenology of oak powdery mildew populations in a common garden}

The five populations of powdery mildew collected at different elevations in the Pyrenees exhibited very similar curves of ascospore release after overwintering under common garden conditions in Villenave d'Ornon (Fig. 3). First spores were trapped in mid-April; a peak was observed 1 month later, followed by a decreasing phase, corresponding to exhaustion of ascospores in chasmothecia.

When comparing phenology of primary infections between in situ and common garden conditions, the ascending phases almost perfectly coincided for populations from low altitude Pyrenean sites. Conversely, phenology was slightly or strongly delayed for populations from intermediate and high altitudes respectively (Fig. 4). It has to be noted that no exhaustion of inoculum was observed under natural conditions (see also Fig. 1), contrary to observations in the cages. In oak stands, conidia produced by primary infections can
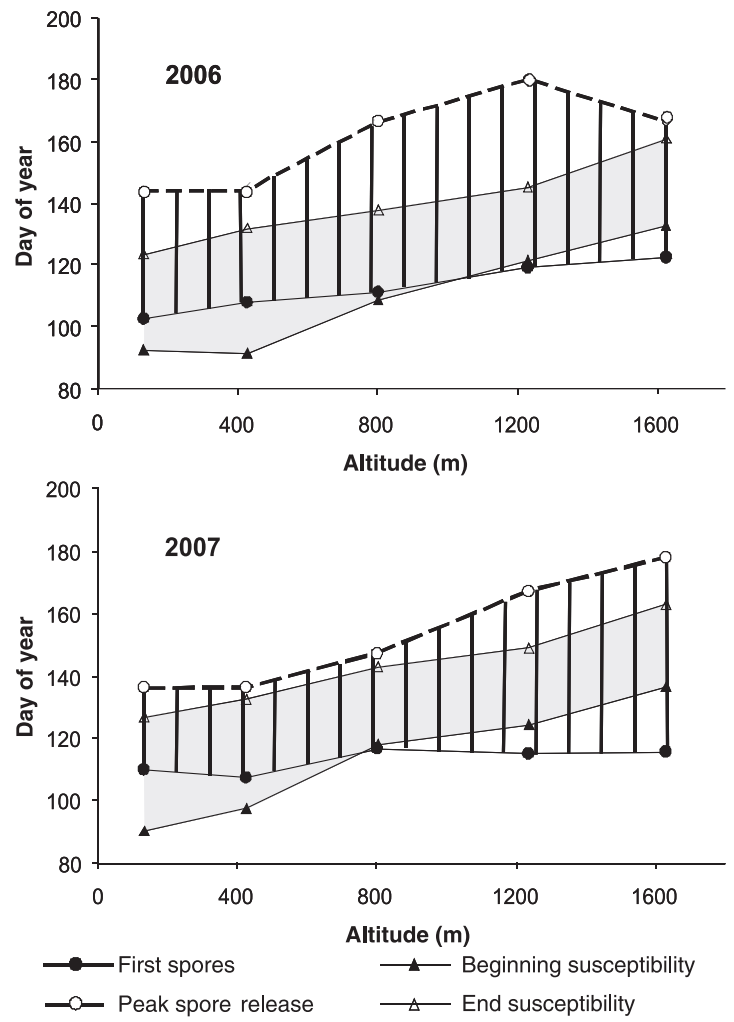

Fig. 2 Phenological synchrony between oaks and Erysiphe alphitoides populations along the altitudinal gradient : the grey area is the receptive period of trees (lower and higher curves $=$ date of occurrence of first susceptible stages in earliest trees and date of occurrence of end of susceptible stages in latest trees respectively); the hatched area is the period of sporulation by the fungus (lower and higher curves = estimated date of occurrence of first spores and date of occurrence of the peak of spore emissions respectively).

initiate secondary cycles of infection after the period of ascospore release whereas inoculum in cages is restricted to that produced from chasmothecia.

\section{Oak infection and relationship with phenology}

Very low infection severity $(<10 \%$ of leaf area infected, on average) was observed for trees located at the lowest 

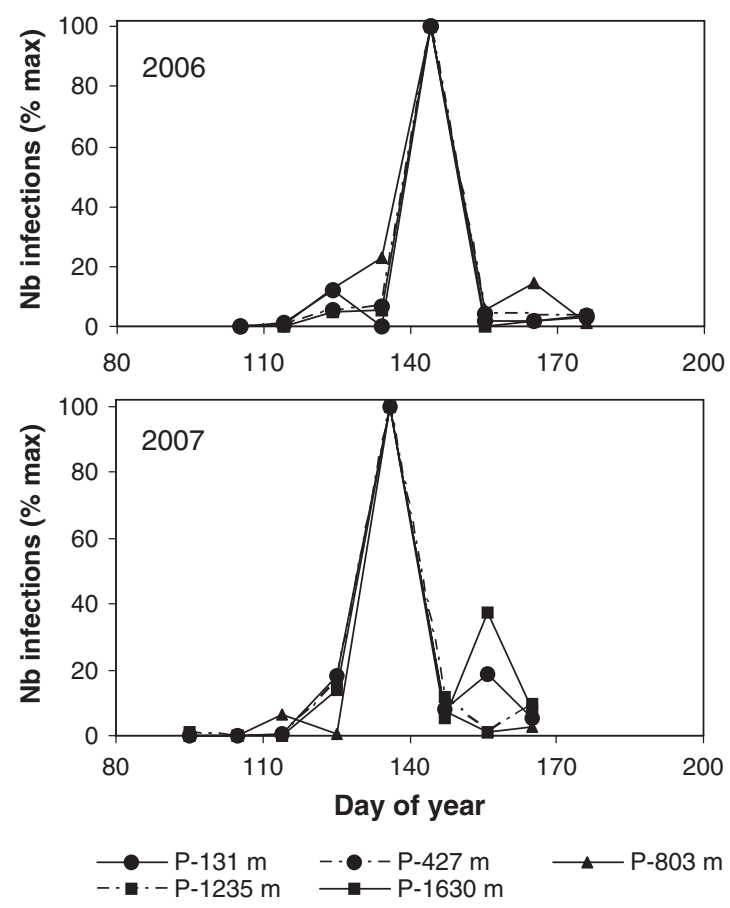

Fig. 3 Spring phenology of oak powdery mildew populations collected along the altitudinal gradient and overwintered in a common garden, monitored as primary infections obtained from chasmothecia on trap seedlings.

and highest elevations, contrary to intermediate elevations $(20-30 \%)$ (Table $4 ; F_{4,44}=5.56, P=0.001$ ).

No general trend between oak phenology and infection was observed along the gradient (Table 4). At the lowest altitude, the five earliest trees (flushing date $<101$ ) showed almost no infection $(<1 \%)$, whereas later flushing trees showed $4-10 \%$ leaf area infected, the highest value being observed for the last flushing tree. The same trend of more severe infections in late-flushing trees was observed at 400 and $1200 \mathrm{~m}$ elevation. Conversely, no relationship was observed at 800 and $1600 \mathrm{~m}$ (Table 4).

\section{Discussion}

The powdery mildew-oak interaction offers an interesting model where co-adaptations for encounter/avoidance are expected to occur and to be affected by environmental changes. Although sessile oak has a large distribution range and oak powdery mildew is a major forest disease in Europe, also present in America and Asia, the biology and genetics of this pathosystem are still poorly known.

A striking result of our study was the differential response of oak and fungus populations to environmental variation (especially temperature) along the altitudinal gradient in their respective and interacting life stages.
Whereas oak leaf phenology was strongly delayed at high altitudes, a relatively low sensitivity of E. alphitoides phenology to altitude was observed in the 2 years of our experiment. The slight cline observed is of the same order of magnitude as that found in a latitudinal gradient between Bordeaux and Nancy (Marçais et al., 2009), when expressed in days of delay per ${ }^{\circ} \mathrm{C}$ decrease, considering annual temperatures (approximately 3 days $/{ }^{\circ} \mathrm{C}$ ). The differential response between the two species resulted in large variation in the phenological match between host and pathogen along the elevation gradient. Using Combes' framework, it can be said that the encounter filter was most widely open at intermediate elevations. Conversely, a significant proportion of trees (the earliest) avoided infections at lower altitudes and a significant proportion of spores could not find susceptible tissues at high altitude.

A second important finding was the lack of evidence from the common garden experiment for genetic differences explaining the phenotypic variation in fungus phenology among populations.

Thus, contrary to expectations, our results suggest a low level of adaptation of oak powdery mildew populations to their host for the encounter filter. A closer examination of phenotypic patterns and possible selective forces at work might explain these observations.

From the fungus side, only the population level could be considered. In agreement with Marçais et al. (2009), our investigation showed that environmental factors explained the largest part of variation in powdery mildew phenology across the Pyrenean transect. The date of primary infections was dependent on the site of overwintering but not on the origin of chasmothecia (Figs 1, 3 and 4). In particular, chasmothecia originating from high altitudes showed substantial changes in their phenology when transferred to low altitude, resulting in roughly the same dynamics of ascospore production as low altitude populations. Conversely, phenology of populations from low altitudes in the Pyrenean gradient was very similar in situ and in the common garden, which can be explained by similar weather, especially temperature, conditions (Table 1 and data not shown). Overall, these results suggest that all or most phenotypic variation in phenology was due to plasticity. Although few studies explored this particular trait, high phenotypic plasticity is considered as a general characteristic of fungi (Andrews, 1992). The genetic control of phenology in fungi has received little attention so far. A notable exception is Monilinia vaccinii-corymbosi, a pathogen of blueberry, for which a differentiation between populations and a significant heritability for the timing of apothecium development were demonstrated (Lehman \& Oudemans, 1997, 2000; Scherm et al., 2001). This may question the lack of genetic differentiation for phenology among oak powdery mildew populations we have found. A major factor determining the extent of adaptive genetic differentiation between populations is the balance between 

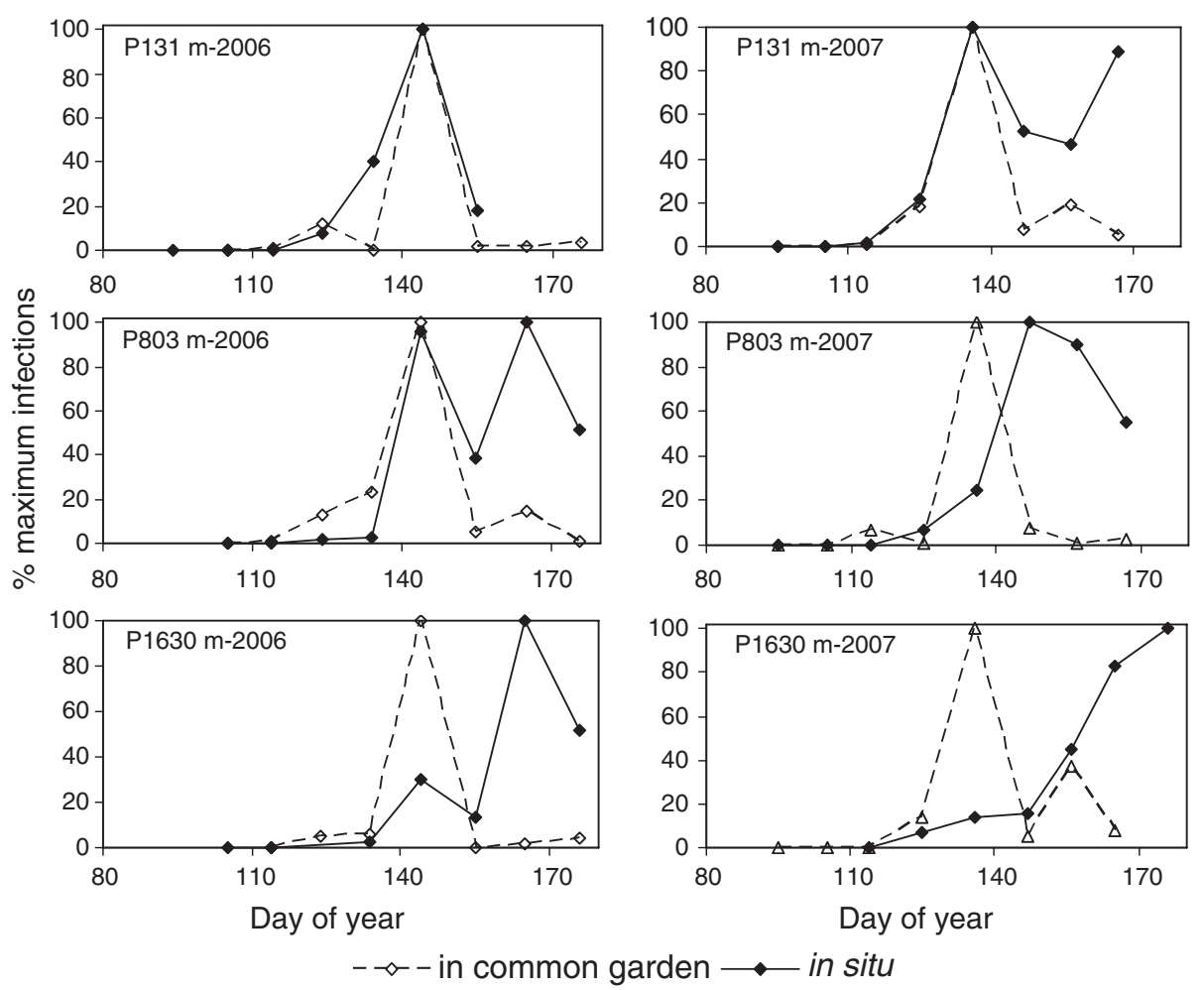

Fig. 4 Comparative spring phenology of oak powdery mildew populations observed in situ (Pyrenean transect) and in the common garden. Phenology was monitored by counting infections on trap seedlings, derived from natural inoculum in the Pyrénées, and from ascospore released from chasmothecia in the common garden.

Table 4 Powdery mildew infection of oaks trees (percentage of leaf area infected) and relationship between individual tree phenology (expressed as number of days from 1 January to leaf unfolding) and infection at the different altitudes.

\begin{tabular}{llll}
\hline Elevation & $\begin{array}{l}\text { Number of } \\
\text { studied } \\
\text { trees }\end{array}$ & $\begin{array}{l}\text { Leaf area } \\
\text { infected (\%) } \\
\text { Mean } \\
\text { (standard deviation) }\end{array}$ & $\begin{array}{l}\text { Phenology } \\
\text { infection } \\
r_{\text {Pearson }}(P)\end{array}$ \\
\hline 131 & 10 & $3.1(3.5)$ & $0.87(0.001)$ \\
427 & 11 & $28.5(25.4)$ & $0.53(0.094)$ \\
803 & 8 & $26.8(18.6)$ & $-0.16(0.70)$ \\
1235 & 9 & $19.3(9.9)$ & $0.60(0.089)$ \\
1630 & 6 & $6.6(6.1)$ & $-0.21(0.68)$ \\
\hline
\end{tabular}

migration and natural selection (Lenormand, 2002). A likely hypothesis for the lack of genetic differentiation between populations of oak powdery mildew could be an insufficient selection pressure on fungus phenology to counteract gene flow. The large variation in oak phenology within stands would preclude consistent selection on phenology in fungus populations. The actual range of variation in oak phenology might be even larger than that observed as only mature trees of Q. petraea were taken into account in our sampling. Phenology of juveniles in many canopy trees in temperate regions predates that of mature trees (Augspurger $\delta$ Bartlett, 2003). The receptive window for the powdery mildew fungus will therefore remain large in each site. Finally, phylogenetic constraints and conflicting selective forces acting on the pathogen, including compatibility with the host or resistance to fungal hyperparasites such as Ampelomyces quisqualis (Kiss, 1998), might also explain the apparent lack of genetic differentiation for phenology at population level in oak powdery mildew.

From the tree side, genetic factors had previously been shown to account for a significant part of the phenological variation within and between populations of $Q$. petraea (Ducousso et al., 1996; Jensen \& Hansen, 2008; Vitasse et al., 2009b) and the related species Q. robur (ScottiSaintagne et al., 2004). Our study demonstrated that oak phenology could be a strong determinant of infection in individual oak trees, therefore the possibility that parasitism acts as a selective force on tree phenology. This was best observed at low altitudes, where earliest trees avoided infections whereas late trees showed a significantly higher percentage of leaf area infected (assumed to be negatively correlated with fitness). Herbivory has also been considered as an important selective force acting on plant phenology (Fenner, 1998; Boege \& Marquis, 2005). Phenological variation among tree individuals within a population was shown to be an effective mechanism for 
protecting trees against high foliage herbivory (Tikkanen \& Julkunen-Tiitto, 2003).

However, besides biotic selective forces, abiotic factors are also thought of as a major determinant in tree phenological adaptation. The timing of leafing can be seen as the best local compromise between maximizing the growing season and the avoidance of frost damage (Kramer, 1995). The timing of flushing in temperate trees, and more generally plant phenology, is thus generally assumed to be the result of an adaptive strategy in response to various biotic and abiotic selective pressures (Rathcke \& Lacey, 1985; Fenner, 1998). The relative contribution of these selective forces may vary with altitude. One may also suspect that the type of selection may vary according to biotic or abiotic drivers resulting in either directional, stabilizing or even disruptive selection. At high elevations, strong directional selection by freezing temperatures might be expected to occur (Agrawal et al., 2004). Conversely, oak mildew pressure might be lower than at lower altitudes, making host-parasite synchrony less critical. Both host and climatic factors (lower tree and foliage densities, shorter growing season, lower temperatures) are a priori less favourable to powdery mildew development than at lower elevations (Glawe, 2008). This might explain the low overall infection observed at $1600 \mathrm{~m}$ (Table 4) although all trees flushed at a time when inoculum was present in relatively large amounts (Figs 1 and 2).

In conclusion, our study demonstrated altitudinal change in host and parasite phenology, with low populations both flushing and sporulating earlier than did high populations. However, populations varied in their host-parasite synchrony along the altitudinal gradient, with low-elevation parasite populations being late and high-elevation parasite populations early with respect to host availability. In addition, we found that most phenotypic variation in parasite phenology was due to phenotypic plasticity. A recent review by Gienapp et al. (2008) pointed to the conclusion that plastic responses to climate change could be more frequent than microevolutionary adaptations, contrary to what was often hypothesized. This does not preclude that there are reciprocal adaptations in the oak-mildew pathosystem. For the trees, the large variation in phenology within populations can be viewed as the result of the diversity of selective forces, among which the parasite could be involved. In turn, the large variation in host phenology encountered by the parasite might explain why no adaptative differentiation could be observed at the scale of each fungal population. For a number of phytophagous insects, it has been shown that adaptive evolution can occur at very fine spatial scales, e.g. at individual tree level within a tree population (Du Merle, 1983). In these interactions, phenology has been considered as a major factor in adaptive deme formation (Mopper et al., 2000; Van Ash \& Visser, 2007). A recent investigation also suggested local adaptation of oak mildew populations at the individual tree level for infectiveness, in spite of apparently extensive efficient gene flow among local mildew populations (Roslin et al., 2007). The oak-powdery mildew pathosystem therefore provides an interesting model for further investigating the roles of plasticity and adaptation at different spatial and genetic scales and taking into account both the encounter and compatibility filters. Furthermore, the study could be expanded to a three-level nested system, including the fungal parasites. The phenology of powdery mildew fungi was suggested to act as a selective force on their Ampelomyces mycoparasites (Szentiványi et al., 2005).

\section{Acknowledgments}

We thank Jean-Marc Louvet, Maïa Lafargue and Mélanie Nunez for technical help. Valuable comments from the two referees and the editor on a previous version of this manuscript are gratefully acknowledged. The Régions Aquitaine and Midi-Pyrénées provided financial support for this study.

\section{References}

Agrawal, A.A., Conner, J.K. \& Stinchcombe, J.R. 2004. Evolution of plant resistance and tolerance to frost damage. Ecol. Lett. 7: 1199-1208.

Alexander, H.M., Antonovics, J. \& Kelly, A.W. 1993. Genotypic variation in plant disease resistance - physiological resistance in relation to field disease transmission. J. Ecol. 81: 325-333.

Andrews, J.H. 1992. Fungal life history strategies. In: The Fungal Community: Its Organization and Role in the Ecosystem, 2nd edn (G.C. Carroll \& D.T. Wicklow, eds), pp. 119-145. Marcel Dekker Inc., New York, NY.

Augspurger, C.K. \& Bartlett, E.A. 2003. Differences in leaf phenology between juvenile and adult trees in a temperate deciduous forest. Tree Physiol. 23: 517-525.

Bent, A.F. \& Mackey, D. 2007. Elicitors, effectors and R genes: the new paradigm and a lifetime supply of questions. Annu. Rev. Phytopathol. 45: 399-436.

Biere, A. \& Antonovics, J. 1996. Sex-specific costs of resistance to the fungal pathogen Ustilago violacea (Microbotryum violaceum) in Silene alba. Evolution 50: 1098-1110.

Biere, A. \& Honders, S. 1996. Impact of flowering phenology of Silene alba and S. dioica on susceptibility to fungal infection and seed predation. Oikos 77: 467-480.

Boege, K. \& Marquis, R.J. 2005. Facing herbivory as you grow up: the ontogeny of resistance in plants. Trends Ecol. Evol. 20: 441-448.

Burdon, J.J. 1987. Diseases and Plant Population Biology. Cambridge University Press, Cambridge, UK.

Butin, H.H. 1995. Tree Diseases and Disorders: Causes, Biology, and Control in Forest and Amenity Trees. Oxford University, Oxford, UK.

Cannell, M.G.R. \& Smith, R.I. 1983. Thermal time, chill days and prediction of budburst in Picea sitchensis. J. Appl. Ecol. 20: 951963.

Chuine, I. \& Cour, P. 1999. Climatic determinants of budburst seasonality in four temperate-zone tree species. New Phytol. 143: 339-349. 
Combes, C. 2001. Ecology and Evolution of Intimate Interactions. Chicago University Press, Chicago, IL.

Desprez-Loustau, M.-L. \& Dupuis, F. 1994. Variation in the phenology of shoot elongation between geographic provenances of maritime pine (Pinus pinaster) - implications for the synchrony with the phenology of the twisting rust Melampsora pinitorqua. Ann. Forest Sci. 51: 553-568.

Desprez-Loustau, M.-L., Capron, G. \& Dupuis, F. 1998. Relating germination dynamics of Melampsora pinitorqua teliospores to temperature and rainfall during overwintering. Eur. J. For. Pathol. 28: 335-347.

Dodd, R.S., Hüberli, D., Mayer, W.T., Harnik, Y., Afzal-Rafii, Z. \& Garbelotto, M. 2008. Evidence for the role of synchronicity between host phenology and pathogen activity in the distribution of sudden oak death canker disease? New Phytol. 179: 505-514.

Du Merle, P. 1983. Comparative phenology of pubescent oak, holly oak and Tortrix viridana L. (Lep., Tortricidae). Evidence for two sympatric populations of the insect each adapted to one of the oaks. Acta Oecol. Oec. Appl. 4: 55-74.

Ducousso, A., Guyon, J.-P. \& Kremer, A. 1996. Latitudinal and altitudinal variation of bud burst in western populations of sessile oak (Quercus petraea (Matt) Liebl). Ann. Forest Sci. 53: 775-782.

Edwards, M.C. \& Ayres, P.G. 1982. Seasonal changes in resistance of Quercus petraea (sessile oak) leaves to Microsphaera alphitoides. T. Brit. Mycol. Soc. 78: 569-571.

Egan, M.J. \& Talbot, N.J. 2008. Genomes, free radicals and plant cell invasion: recent developments in plant pathogenic fungi. Curr. Opin. Plant Biol. 11: 367-372.

Elmqvist, T., Liu, D., Carlsson, U. \& Giles, B. 1993. Anthersmut infection in Silene dioica: variation in floral morphology and patterns of spore deposition. Oikos 68: 207-216.

Fenner, M. 1998. The phenology of growth and reproduction in plants. Perspect. Plant Ecol. Evol. Syst. 1: 78-91.

Gandon, S. \& Michalakis, Y. 2002. Local adaptation, evolutionary potential and host-parasite coevolution: interactions between migration, mutation, population size and generation time. J. Evol. Biol. 15: 451-462.

Gandon, S. \& Van Zandt, P.A. 1998. Local adaptation and hostparasite interactions. Trends Ecol. Evol. 13: 214-216.

Gienapp, P., Teplitsky, C., Alho, J.S., Mills, J.A. \& Merila, J. 2008. Climate change and evolution: disentangling environmental and genetic responses. Mol. Ecol. 17: 167-178.

Glawe, D.A. 2008. The powdery mildews: a review of the world's most familiar (yet poorly known) plant pathogens. Annu. Rev. Phytopathol. 46: 27-51.

Greischar, M.A. \& Koskella, B. 2007. A synthesis of experimental work on parasite local adaptation. Ecol. Lett. 10: 418434.

Hanninen, H. 1995. Effects of climatic change on trees from cool and temperate regions: an ecophysiological approach to modelling of budburst phenology. Can. J. Bot. 73: 183199.

Jensen, J.S. \& Hansen, J.K. 2008. Geographical variation of phenology of Quercus petraea (Matt.) Liebl and Q. robur L. oak grown in a greenhouse. Scand. J. Forest Res. 23: 179-188.

Jones, J.D.G. \& Dangl, J.L. 2006. The plant immune system. Nature 444: 323-329.

Kaltz, O. \& Shykoff, J.A. 1998. Local adaptation in host-parasite systems. Heredity 81: 361-370.
Kaltz, O. \& Shykoff, J.A. 2001. Male and female Silene latifolia plants differ in per-contact risk of infection by a sexually transmitted disease. J. Ecol. 89: 99-109.

Kiss, L. 1998. Natural occurrence of Ampelomyces mycoparasites in mycelia of powdery mildew fungi. New Phytol. 140: 709714.

Kramer, K. 1995. Phenotypic plasticity of the phenology of seven European tree species, in relation to climatic warming. Plant Cell Environ. 18: 93-104.

Lehman, J.S. \& Oudemans, P.V. 1997. Phenology of apothecium production in populations of Monilinia vaccinii-corymbosi from early- and late-maturing blueberry cultivars. Phytopathology 87: 218-223.

Lehman, J.S. \& Oudemans, P.V. 2000. Variation and heritability of phenology in the fungus Monilinia vaccinii-corymbosi on blueberry. Phytopathology 90: 390-395.

Lenormand, T. 2002. Gene flow and the limits to natural selection. Trends Ecol. Evol. 17: 183-189.

Marçais, B., Kavkova, M. \& Desprez-Loustau, M.-L. 2009. Phenotypic variation in the phenology of ascospore production between European populations of oak powdery mildew. Ann. For. Sci. in press.

de Meaux, J. \& Mitchell-Olds, T. 2003. Evolution of plant resistance at the molecular level: ecological context of species interactions. Heredity 91: 345-352.

Memmott, J., Craze, P.G., Waser, N.M. \& Price, M.V. 2007. Global warming and the disruption of plant-pollinator interactions. Ecol. Lett. 10: 710-717.

Meyers, B.C., Kaushik, K. \& Nandety, R.S. 2005. Evolving disease resistance genes. Curr. Opin. Plant Biol. 8: 129-134.

Mopper, S., Stiling, P., Landau, K., Simberloff, D. \& van Zandt, P. 2000. Spatiotemporal variation in leafminer population structure and adaptation to individual oak trees. Ecology 81: 15771587.

Mougou, A., Dutech, C. \& Desprez-Loustau, M.-L. 2008. New insights into the identity and origin of the causal agent of oak powdery mildew in Europe. For. Pathol. 38: 275-287.

Ovaskainen, O. \& Laine, A.-L. 2006. Inferring evolutionary signals from environmenral data in a plant-pathogen metapopulation. Ecology 87: 880-891.

Penman, L.N. \& Annis, S.L. 2005. Leaf and flower blight caused by Monilinia vaccinii-corymbosi on lowbush blueberry: effects on yield and relationship to bud phenology. Phytopathology 95 : 1174-1182.

Rathcke, B. \& Lacey, E.P. 1985. Phenological patterns of terrestrial plants. Annu. Rev. Ecol. Syst. 16: 179-214.

Roslin, T., Laine, A.-L. \& Gripenberg, S. 2007. Spatial population structure in an obligate plant pathogen colonizing oak Quercus robur. Funct. Ecol. 21: 1168-1177.

Rossi, V., Caffi, T., Bugiani, R., Spanna, F. \& Della Valle, D. 2008. Estimating the germination dynamics of Plasmopara viticola oospores using hydro-thermal time. Plant Pathol. 57: 216-226.

Salvaudon, L., Giraud, T. \& Shykoff, J. 2008. Genetic diversity in natural populations: a fundamental component of plantmicrobe interactions. Curr. Opin. Plant Biol. 11: 135-143.

Scherm, H., Savelle, A.T. \& Pusey, L.P. 2001. Interactions between chill-hours and degree-days affect carpogenic germination in Monilinia vaccinii-corymbosi. Phytopathology 91: 77-83.

Scotti-Saintagne, C., Bodénès, C., Barreneche, T., Bertocchi, E., Plomion, C. \& Kremer, A. 2004. Detection of quantitative trait 
loci controlling bud burst and height growth in Quercus robur L. Theor. Appl. Genet. 109: 1648-1659.

Shykoff, J.A., Bucheli, E. \& Kaltz, O. 1997. Anther smut disease in Dianthus sylvestris (Caryophyllaceae): natural selection on floral traits. Evolution 5: 383-392.

Sicard, D., Pennings, P.S., Grandclément, C., Acosta, J., Kaltz, O. \& Shykoff, J.A. 2007. Specialization and local adaptation of a fungal parasite on two host species as revealed by two fitness traits. Evolution 61: 27-41.

Szentiványi, O., Kiss, L., Russell, J.C., Kovács, G.M., Varga, K., Jankovics, T., Lesemann, S., Xu, X.M. \& Jeffries, P. 2005. Ampelomyces mycoparasites from apple powdery mildew identified as a distinct group based on single-stranded conformation polymorphism analysis of the rDNA ITS region. Mycol. Res. 109: 429-438.

Thrall, P.H. \& Jarosz, A.M. 1994. Host-pathogen dynamics in experimental populations of Silene alba and Ustilago violacea. I. Ecological and genetic determinants of disease spread. Ecology 82: 549-559.

Tiffin, P. \& Moeller, D.A. 2006. Molecular evolution of plant immune system genes. Trends Genet. 22: 662-670.
Tikkanen, O.-P. \& Julkunen-Tiitto, R. 2003. Phenological variation as protection against defoliating insects: the case of Quercus robur and Operophtera brumata. Oecologia 136: 244-251. Van Ash, M. \& Visser, M.E. 2007. Phenology of forest caterpillars and their host trees: the importance of synchrony. Annu. Rev. Entomol. 52: 37-55.

Visser, M.E. \& Holleman, L.J.M. 2001. Warmer springs disrupt the synchrony of oak and winter moth phenology. Proc. Biol. Sci. 268: 89-94.

Vitasse, Y., Delzon, S., Dufrêne, E., Pontailler, J.-Y., Louvet, J.-L., Kremer, A. \& Michalet, R. 2009a. Leaf phenology sensitivity to temperature in European trees: do withinspecies populations exhibit similar responses? Agr. For. Meteorol. 149: 735-744.

Vitasse, Y., Delzon, S., Bresson, C.C., Michalet, R. \& Kremer, A. 2009b. Altitudinal differentiation in growth and phenology among populations of temperate tree species growing in a common garden. Can. J. For. Res. 39: 1259-1289.

Received 23 June 2009; revised 14 September 2009; accepted 22 September 2009 